\title{
CHANGES EFFECT OF SUGAR IMPORT TARIFF IN INDONESIA
}

\author{
Agnes Q. Pudjiastuti, Doctoral Candidate in Agricultural Economics \\ Ratya Anindita, Professor in Agricultural Economics \\ Nuhfil Hanani, David Kaluge, Researchers \\ University of Brawijaya, Indonesia \\ E-mail: ratyaa@ub.ac.id
}

\begin{abstract}
The purpose of this paper is to study the effect of sugar import tariffs changes since the tariff import is the only policy to increase the sugar domestic production. This analysis is performed using a CGE (computable general equilibrium) model of Indonesian economy in 2008. Results showed that the increases of sugar import tariff have some different conclusions. If sugar tariff import will rise to $41.6 \%$ and to $50 \%$, the domestic output of sugar will increase about $1.89 \%$ and $3.77 \%$; and household welfare would increase about 0.52 and $0.76 \%$, respectively. But when the sugar import tariff is removed, domestic output of sugar and sugarcane have not changed, but the agricultural sector would reduce and income of all agents would decrease. Thus, the relevant tariff depends on the purpose of the government whether to increase domestic output and import or export of certain sectors, and the welfare of producers or consumers.
\end{abstract}

\section{KEYWORDS}

Sugar; Import tariff; Domestic output; Export; Import; Household welfare, Computable general equilibrium.

Indonesian sugar has included as the sensitive list in AFTA (ASEAN Free Trade Agreement) since 1996. The sensitive list products would make Indonesia to protect the commodity by import tariff which Indonesia could assign the maximum tariff of $40 \%$ (Secretariat of the Republic of Indonesia, 2009). This instrument was used to accelerate the sugar production growth to attain the self-sufficiency of sugar (Ministry of Industry, 2009).

The Indonesian sugar production accounted for 2.0 million tons in 2004 and it increased to 2.7 million tons in 2008. However the import was increased from 1.5 million to 2.9 million in the same years due to the increase of domestic consumption. The lack of production and consumption was encouraging the government to boost the production by the import tariff. If the price of sugar import less expensive than domestic sugar prices, then the domestic sugar output will fall from not being able to compete with imported sugar. As a small country in the world sugar trade, Indonesia is not able to influence the world price. As a result, the low of the world sugar prices will be transmitted directly to the market of sugar Indonesia so that the price of imported sugar is also inexpensive. Therefore, the Indonesian government set a tariff to protect the domestic sugar producers. However, the import tariff that is imposed in Indonesia is still lower than tariff that are allowed by AFTA and optimal tariff by empirical study that is equal to 50 percent.

On the other hand, import tariffs setting will cause the price of imported sugar is higher. If the consumer's money income is relatively fixed, the consumer purchasing power will fall. While the rise in the price of sugar in the domestic market in response to the raise import prices would also cause the poor of competitiveness of the food and beverage industry and other industries which are consumer industries of sugar. Meanwhile, the abolition of import tariffs as a requirement the liberalization will lower the import prices could hurt the manufacturers. However, according to Anindita and Reed (2008), when the tariff is removed, there will be a scheme to pay the damages because of the welfare of domestic producers in the economy will increase.

Therefore, the effect of changes in sugar import tariffs towards domestic output, exports and imports, as well as the households income and households welfare in Indonesia in the context of the general equilibrium needs to be assessed to find out the compatible of import tariffs in order to increase sugar production. 


\section{THEORITICAL REVIEW}

The Effect of Import Tariff. In developing countries, international trade has an important role. The trade which is introduced to the CGE framework will be able to represent the foreign trade and trade policy (Shoven and Whalley, 1992). According to Just et al. (1982), an open economy under the trade, each country may have limited of the technology and resources endowment. The gains from trade are a country can export the products that use a relatively abundant resources and import the products using a relatively scarce resources. The effect of trade policies, such as a tariff, considered in trade between countries with emphasis on the distribution of the gains from trade. If the ad valorem tariff for i sectors represented by notation $\mathrm{tm}_{\mathrm{i}}$, the domestic prices in the economy linked to world prices through:

$$
P_{i}=\overline{P W}_{i}\left(1+t m_{i}\right) E R i \in T
$$

where $\mathrm{T}$ represents a set of the tradable sector. For a small open economy, the world price $\left(\overline{P W}_{i}\right)$ is fixed exogenously, so that trade policies can fully define the relative domestic price of tradable goods. For each pair of the sector:

$$
\frac{P_{i}}{P_{j}}=\frac{\overline{P W}_{i}\left(1+t m_{i}\right)}{\overline{P W}_{j}\left(1+t m_{j}\right)}
$$

because of the exchange rate were excluded from the model. Therefore, import tariffs have an important role in the small open economy model. The tariff effect in the economy of the two tradable sectors and the standard model without any distortions in the factor markets or commodity markets were drawn in Figure 1.

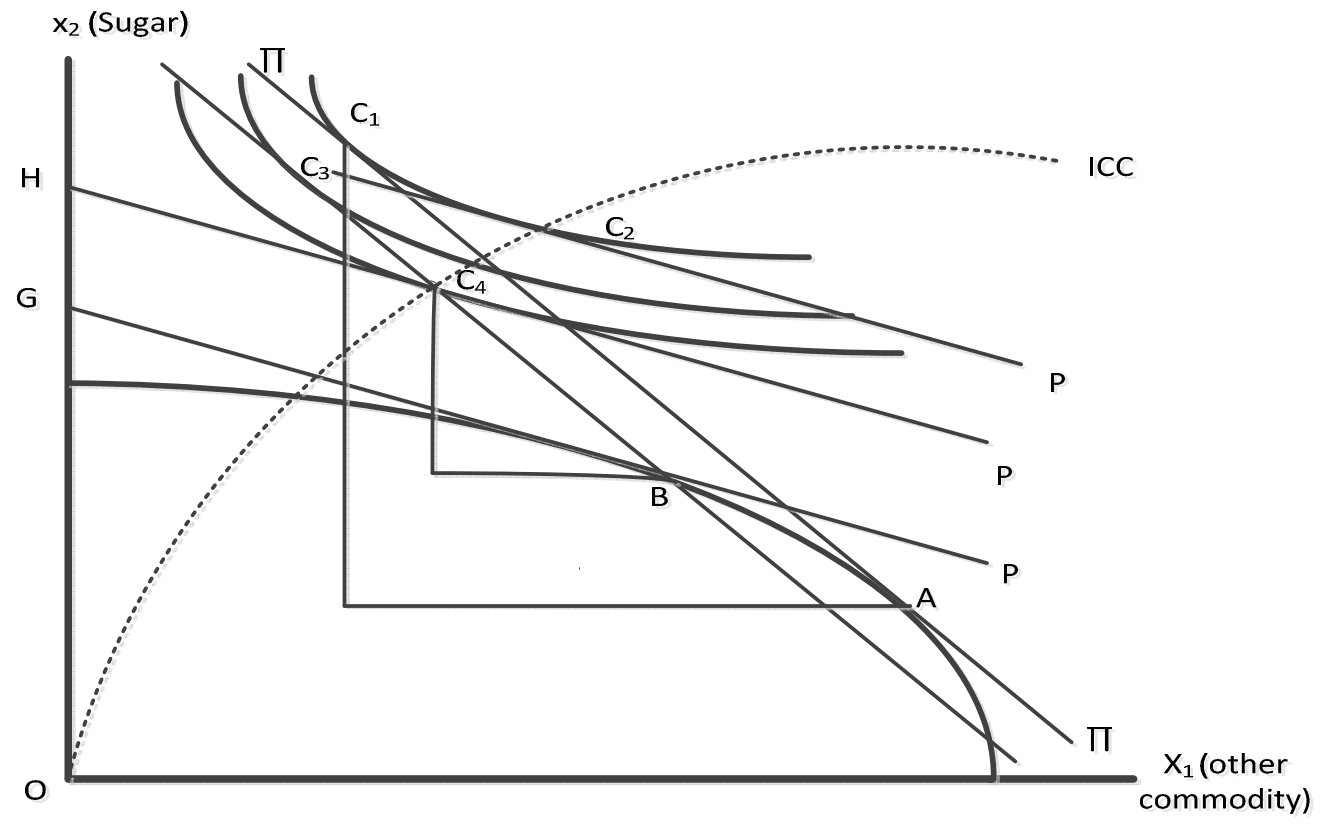

Figure 1. Sugar Import Tariff Effect on Production, Consumption and Trade Source: Adapted from Just et al. (1982)

Under free trade, production occur in $\mathrm{A}$ and consumption occur in $\mathrm{C} 1$. The world price ratio $\Pi=\overline{P W}_{1} / \overline{P W}_{2}$ equal to the ratio of domestic prices. Import tariff of sugar will reduce the relative domestic price below the world price, which is indicated by the line $P$. This tariff generate an effect called: (1) the effect of production in which producers turned to the production of imported goods ( $\rightarrow B$ ), (2) the effects of government revenue is $\mathrm{GH}$, because 
the government collects revenues from rates, (3) a reduction in trade volume, indicated the relative size of the two triangular trade, (4) the effect of welfare, as long as society moves to the lower indifference curve and eventually consume in C3. The movement from $\mathrm{C} 1$ to $\mathrm{C} 3$ can be determined using the income consumption line is denoted by the ICC, because of the substitution effect $(\mathrm{Cl} \rightarrow \mathrm{C} 2)$ and the income effect $(\mathrm{C} 2 \rightarrow \mathrm{C} 3)$.

The Welfare Measurement. A different tariff policy will make consumers (households) better off or worse off. According to Varian (1992), the changes in household welfare in the context of a policy changes would be more appropriate if it is measured by the compensating and equivalent variations (CV and EV). In brief, EV can be defined as the change in income as large as the effect of price changes on consumer utility. CV is defined as the amount of money needed to keep consumers can reside on the same utility as before the price change. Hanemann and Morey (1992) also states that the CV and EV is an appropriate measurement for welfare changes as the effects of a policy.

In CGE models, the impacts of given shocks or policies on households welfare can measured by using the money metric utility function, which measures the nominal income the consumer needs at one set of prices in order to be as well of at an alternative set of prices and nominal income. As such, it can be used to obtain monetary measures of the welfare effects of different policy scenarios (Robichaud, 2001).

Let us first define the utility function, $\mu(C)$, the indirect utility function, $v(P, Y)$ and the money metric indirect utility function, $m(P, \mu)$. In these expressions, $C$ represents the vector of goods consumed, $P$ the vector of prices and $Y$ household income. Equation (1) represents the utility function for a Cobb-Douglas specification.

$$
\begin{gathered}
\mu(C)=\prod_{i=1}^{I} C_{i}^{\alpha_{i}}(1) \\
\text { where } \sum_{i=1}^{I} \alpha_{i}=1
\end{gathered}
$$

Given these specifications, demand functions are derived by maximizing utility subject to the budget constraint:

$$
C_{i}(P, Y)=\frac{\alpha_{i} Y}{P_{i}}(2)
$$

The indirect utility function, $v(P, Y)$, is obtained by replacing the $C_{i}$ in the utility functions (1) with the demand functions (2):

$$
v(P, Y)=\prod_{i=1}^{I}\left[\frac{\alpha_{i} Y}{P_{i}}\right]^{\alpha_{i}}
$$

Solving equation (3) for $Y$ gives the money metric indirect utility function, $m(P, v)$, which is a measure of the income needed to attain utility level $v$ at the vector of prices $P$ :

$$
m(P, v)=\prod_{i=1}^{I}\left[\frac{\alpha_{i} Y}{P_{i}}\right]^{\alpha_{i}} v(4)
$$

Equivalent and compensating variations are welfare measures based on the money metric indirect utility function:

$$
\begin{aligned}
& E V=m\left(P_{i}^{0}, v\left(P_{i}^{1}, Y^{1}\right)\right)-m\left(P_{i}^{0}, v\left(P_{i}^{1}, Y^{1}\right)\right)=m\left(P_{i}^{0}, v\left(P_{i}^{1}, Y^{1}\right)\right)-Y^{0} \\
& C V=m\left(P_{i}^{1}, v\left(P_{i}^{1}, Y^{1}\right)\right)-m\left(P_{i}^{1}, v\left(P_{i}^{0}, Y^{0}\right)\right)=Y^{1}-m\left(P_{i}^{1}, v\left(P_{i}^{0}, Y^{0}\right)\right)
\end{aligned}
$$

We use equation (3) and (4) to obtain:

$$
E V=m\left(P_{i}^{0}, v\left(P_{i}^{1}, Y^{1}\right)\right)-Y^{0}=\prod_{i=1}^{I}\left[\frac{P_{i}^{0}}{\alpha_{i}}\right]^{\alpha_{i}} v\left(P_{i}^{1}, Y^{1}\right)-Y^{0}
$$




$$
\begin{aligned}
=\prod_{i=1}^{I}\left[\frac{P_{i}^{0}}{\alpha_{i}}\right]^{\alpha_{i}} \prod_{i=1}^{I}\left[\frac{\alpha_{i} Y^{1}}{P_{i}^{1}}\right]^{\alpha_{i}}-Y^{0}=\prod_{i=1}^{I}\left[\frac{P_{i}^{0}}{\alpha_{i}}\right]^{\alpha_{i}} Y^{1}-Y^{0} \\
C V=Y^{1}-m\left(P_{i}^{1}, v\left(P_{i}^{0}, Y^{0}\right)\right)=Y^{1}-\prod_{i=1}^{I}\left[\frac{P_{i}^{1}}{\alpha_{i}}\right]^{\alpha_{i}} v\left(P_{i}^{0}, Y^{0}\right) \\
=Y^{1}-\prod_{i=1}^{I}\left[\frac{P_{i}^{1}}{\alpha_{i}}\right]^{\alpha_{i}} \prod_{i=1}^{I}\left[\frac{\alpha_{i} Y^{0}}{P_{i}^{0}}\right]^{\alpha_{i}}=Y^{1}-\prod_{i=1}^{I}\left[\frac{P_{i}^{1}}{P_{i}^{0}}\right]^{\alpha_{i}} Y^{0}
\end{aligned}
$$

Obi-Egbedi et al. (2012), also evaluated to welfare implications of rice trade policy on households were estimated by calculating welfare gains/losses from simulation results with Hicksian Equivalent Variations (EV) following the previous researchers. The Hicksian EV was given by

$$
E V^{h}=\left[\frac{U_{n}^{h}-U_{0}^{h}}{U_{0}^{h}}\right] Y_{0}^{h}
$$

Where $Y_{0}^{h}$ is the income of household $\mathrm{h}$ before the policy change, $U_{0}^{h}$ is the utility of household $\mathrm{h}$ before the policy change, $U_{n}^{h}$ is the utility of household $\mathrm{h}$ after the policy change and $E V^{h}$ is the Equivalent Variation of a household $\mathrm{h}$.

\section{METHODOLOGY}

This study used data tables Input-Output (IO) and Social Accounting Matrix (SAM) of Indonesia in 2008. It also used a few parameters such as the elasticity estimates for obtained from the previous studies. The data sources in this study is the Central Statistics Agency (BPS) and the results of previous studies.

To evaluate the effects of changes in sugar import tariffs on sectoral economic performance, household income and household welfare in Indonesia is used CGE models with GAMS-MPSGE software. The model is built based on a common model by Hosoe, et al. (2010) and a specific model that was developed by Lofgren, et al. (2002), Woods-Early (2006) and Markusen and Rutherford (2004).

CGE models were developed for Indonesia's sugar industry is a static CGE models for a single economy, an open and small. In addition, it is also assumed that there is a perfectly competitive market, supply of production factors are fixed, and labor has been used entirely (full employment), the primary inputs are fully mobile across sectors and production is constant returns to scale. Households are divided into eight groups, while the labor force is divided into skilled and unskilled. Other factors of production, namely capital is not disaggregated.

Indonesia does not discriminate all sources of imports, and it is assumed that the supply of goods distinguished on the domestic goods and imports, so that the export prices and import prices in Indonesia is different. In other words, trade is modeled using the Armington assumption (1969), in which the intermediate inputs and finished goods are differentiated by source of imported and domestic. Meanwhile, the consumer will maximize utility function with budget constraints.

\section{RESULTS AND DISCUSSION}

The simulation have been done in this study consists of a) rising sugar import tariff to $40 \%$ in accordance with AFTA, b) increasing sugar import tariff rate of $5 \%$ according to the proposed sugar associations, c) rising import tariffs by $50 \%$, i.e. the optimal sugar import tariff for Indonesia based on previous research, and d) removing the sugar import tariff in 
accordance with free trade. Sugar import tariffs in the base was $36.6 \%$, in which the simulation is based on this figure. Here is described the effects of the four simulations for domestic output, exports and imports for all sectors, households income and households welfare in Indonesia.

Effects on Domestic Output Volume. Sugar import tariff changes have positive and negative effects on domestic output (see Table 1). If the sugar import tariff less than $50 \%$ will reduce domestic output of food crops sector, agriculture and other services, but other sectors such as sugar, sugarcane, fertilizer and pesticide industry, food and beverage industry, and other industries will increase. But if the tariff equal to $50 \%$, sugar producers and other sectors will increase their production.

Table 1. The Change of Domestic Output Volume

\begin{tabular}{|c|c|c|c|c|c|c|}
\hline \multirow{2}{*}{ No } & \multirow{2}{*}{ Sectors } & \multirow{2}{*}{ Baseline (Trillion Rp) } & \multicolumn{4}{|c|}{ The change of domestic output volume (\%) } \\
\hline & & & $\operatorname{Sim} 1$ & Sim 2 & $\operatorname{sim} 3$ & Sim 4 \\
\hline 1 & Food Crops & 446 & $-6,73$ & $-5,83$ & 1,57 & $-6,73$ \\
\hline 2 & Sugarcane Plantation & 26 & 0 & 11,54 & 7,69 & 0 \\
\hline 3 & Other Agricultural Crops & 713 & $-4,42$ & $-1,19$ & 7,46 & $-4,42$ \\
\hline 4 & Sugar Industry & 53 & 0 & 3,77 & 1,89 & 0 \\
\hline 5 & Food and Beverage Industry & 669 & 1,20 & 3,44 & 3,44 & 1,20 \\
\hline 6 & Fertilizer and Pesticide Industry & 46 & 0 & 2,17 & 2,17 & 0 \\
\hline 7 & Other Industries & 4.517 & 0,30 & 1,7 & 5,24 & 0,30 \\
\hline 8 & Services & 16.771 & $-10,07$ & 3,87 & 17,39 & $-10,12$ \\
\hline
\end{tabular}

Description: baseline: import tariffs currently at 36.6\%; sim 1: import tariffs on sugar rise 40\%; sim 2: Rates of sugar imports rise 5\% to 41.6\%; sim 3: sugar import tariff rise to 50\%; sim 4: sugar import tariff removal $(0 \%$.)

This is indicates a substitution between the area used to plant sugarcane as the raw material of sugar and the area of land used for food crops. Its mainly be assessed in this case is: 1) whether the increase value of domestic supply of various sectors is greater than the decline in the value of domestic supply of food and other agricultural crops, and 2) how the decline in domestic supply food crops as a result of changes in the sugar import tariff does not interfere with food security in Indonesia. Mapfumo et al. (2012) claimed that the agricultural sector plays an important role in economic growth.

According to the Stolper-Samuelson theorem, the output price increases will cause a rise in production factors prices are widely used in the production of this output. In the context of this study, the rise in sugar prices which will lead to higher prices responded by sugar and sugarcane producers to increase their production.

Effects on Export Volumes. The changes in sugar import tariff also has positive and negative effects on the volume of exports of all sectors, except for sugar industry and sugarcane sector (see Table 2). When the sugar import tariffs rise at $50 \%$, the volume of export crops sector, other agriculture, food and beverage, fertilizers and pesticides industry as well as other industries will rise.

Table 2. The Change of Export Volume

\begin{tabular}{|c|c|c|c|c|c|c|}
\hline \multirow{2}{*}{ No } & \multirow{2}{*}{ Sectors } & \multirow{2}{*}{ Baseline (Trillion Rp) } & \multicolumn{4}{|c|}{ The change of export volume (\%) } \\
\hline & & & Sim 1 & Sim 2 & $\operatorname{sim} 3$ & Sim 4 \\
\hline 1 & Food Crops & 0,857 & 0,02 & 16,72 & 16,72 & $-2,73$ \\
\hline 2 & Sugarcane Plantation & 0 & 0 & 0 & 0 & 0 \\
\hline 3 & Other Agricultural Crops & 41,033 & 0,02 & 382,42 & 382,42 & 0 \\
\hline 4 & Sugar Industry & 0 & 0 & 0 & 0 & 0 \\
\hline 5 & Food and Beverage Industry & 407 & 0,25 & 3,02 & 3,28 & 0,25 \\
\hline 6 & Fertilizer and Pesticide Industry & 4 & 0 & 50,00 & 50,00 & 0 \\
\hline 7 & Other Industries & 2.127 & 0,21 & 2,16 & 2,05 & 0,21 \\
\hline 8 & Services & 200,979 & 0 & 560,32 & 560,32 & 0 \\
\hline
\end{tabular}

These findings are interesting because in the production structure has been explained that the domestic output will be sold in the domestic market and in the foreign markets 
(export). If it is assumed that a country will export after its domestic demand fulfilled, so if domestic output rises, the export will also rise. However, all of agriculture sectors except for sugarcane have different tendencies. Domestic output of this sector have decreased, but exports have increased. There are indications that a decline in the volume of sales (consumption) of agricultural commodities in the domestic market with an increase in sugar import tariffs.

If the sugar import tariffs is removed, only the food and beverage industry and other industries to increase its volume of exports, while the export volume of food crops will decrease. Decline in the exports of food crops caused by the decrease of domestic output in this sector.

Effects on Import Volume. Changes in sugar import tariffs varied effect on the volume of imports (see Table 3). The higher the sugar import tariffs, the higher the volume of imports of food crops, sugarcane, food and beverage industry, fertilizers and pesticides industry, as well as other industries, but the volume of imports of other agricultural and services decreases. Meanwhile, the abolition of sugar import tariffs, will only increase the volume of sugarcane and other agricultural imports amounted to $0.03 \%$ and $0.15 \%$, other sectors have not changed. Imported sugar 2 trillion rupiah Indonesia is still being done despite the tariff increased to $50 \%$.

Table 3. The Change of Import Volume

\begin{tabular}{|c|c|c|c|c|c|c|}
\hline \multirow{2}{*}{ No } & \multirow{2}{*}{ Sectors } & \multirow{2}{*}{ Baseline (Trillion Rp) } & \multicolumn{4}{|c|}{ The change of import volume (\%) } \\
\hline & & & $\operatorname{Sim} 1$ & $\operatorname{Sim} 2$ & $\operatorname{Sim} 3$ & Sim 4 \\
\hline 1 & Food Crops & 29 & 0,01 & 6,45 & 9,68 & 0 \\
\hline 2 & Sugarcane Plantation & 0,009 & 0,15 & 272,31 & 289,11 & 0,15 \\
\hline 3 & Other Agricultural Crops & 17,813 & 0,01 & $-10,17$ & $-10,16$ & 0,03 \\
\hline 4 & Sugar Industry & 2 & 0 & 0 & 0 & 0 \\
\hline 5 & Food and Beverage Industry & 36 & 0 & 2,63 & 2,63 & 0 \\
\hline 6 & Fertilizer and Pesticide Industry & 24 & 0 & 4,17 & 4,17 & 0 \\
\hline 7 & Other Industries & 1.332 & 0 & 10,82 & 10,73 & 0 \\
\hline 8 & Services & 176 & 0 & $-2,27$ & $-2,27$ & 0 \\
\hline
\end{tabular}

As described earlier in the structure of production, domestic demand for intermediate inputs, final goods, and investments comes from domestic output and imports. Imported sugar is still being done shows that the increase in import tariffs that result in higher prices for sugar have not been interesting Indonesian sugar producers to increase their production.

Effects on Household Income. The changes import tariffs of sugar have different effects on household income, producers income and government income (see Table 4). Sugar import tariff at $0 \%, 40 \%$ and $50 \%$ would decrease the farm households income 2.30 $4.15 \%$, non-farm rural household $2.29-4.13 \%$ and non-farm urban households $2.29-4.13 \%$. But sugar import tariff at $41.6 \%$ has the effect of improve the farm household income from 0.36 to $0.37 \%$, non-farm rural households from 0.38 to $0.42 \%$ and non-farm urban households from 0.39 to $0.43 \%$.

Table 4. The Change of Households Income

\begin{tabular}{|c|c|c|c|c|c|}
\hline \multirow{2}{*}{ Household Classifications } & \multirow{2}{*}{$\begin{array}{l}\text { Baseline } \\
\text { (Triliun Rp) }\end{array}$} & \multicolumn{4}{|c|}{ The change of income (\%) } \\
\hline & & Sim 1 & $\operatorname{Sim} 2$ & $\operatorname{sim} 3$ & Sim 4 \\
\hline Farm-Worker Households & 7.041 & $-2,30$ & 0,37 & $-4,13$ & $-2,30$ \\
\hline Agricultural-Entrepreneur Households & 7.135 & $-2,30$ & 0,36 & $-4,15$ & $-2,30$ \\
\hline Low-Income Rural Households & 7.014 & $-2,30$ & 0,38 & $-4,13$ & $-2,30$ \\
\hline Non-Labor Force Rural Households & 6.595 & $-2,30$ & 0,41 & $-4,11$ & $-2,30$ \\
\hline High-Income Rural Households & 6.506 & $-2,31$ & 0,42 & $-4,10$ & $-2,31$ \\
\hline Low-Income Urban Households & 6.929 & $-2,29$ & 0,39 & $-4,13$ & $-2,29$ \\
\hline Non-Labor Force Urban Households & 6.582 & $-2,29$ & 0,41 & $-4,10$ & $-2,29$ \\
\hline High-Income Ürban Households & 6.553 & $-2,29$ & 0,43 & $-4,09$ & $-2,29$ \\
\hline Firms & 11.579 & $-12,83$ & $-14,84$ & $-12,66$ & $-12,83$ \\
\hline Government & 6.731 & $-2,29$ & $-0,21$ & $-4,62$ & $-2,29$ \\
\hline
\end{tabular}


Tariff will increase the import parity prices so that domestic prices also increased. Because of the sugar is one of the basic needs of the households, an increase in this commodity price will cause an increase in the other commodity prices. As a result of increased price of a basket commodity that is consumed is the decline in real income of the households with the assumption that nominal income unchanged.

Producers and government revenues also decreased with the change of sugar import tariffs. If the of sugar import tariffs rise by $50 \%$, the income of producers will decline from 12.66 to $14.84 \%$, while the government revenue will decline from 0.21 to $4.62 \%$. Referring to the Stolper-Samuelson theorem, the tariffs will increase the production cost of a commodity. The marginal cost is greater than the value of the marginal product will cause a decrease in revenues (gains) of producers.

Effects on Household Welfare. The changes of sugar import tariffs has a positive effect on households welfare, but has a negative effect on the firms welfare (see Table 5). The results showed that if the sugar import tariffs established on $0 \%$ and $40 \%$, so the welfare of farm households and non-agriculture households is relatively fixed. If the tariff increased $41.6-50 \%$, the welfare of farm households rise $0.52-0.69 \%$, non-farm rural households rise $0.70-0.76 \%$ and non-farm urban households rise $0,53-0.75 \%$. According to Munongo (2012), increasing livelihood in rural areas is important to progress developing world and it helps in the creation of the domestic demand for the productive sector.

Table 5. The Change of Households Welfare

\begin{tabular}{|c|c|c|c|c|c|}
\hline \multirow{2}{*}{ Household Classifications } & \multirow{2}{*}{$\begin{array}{l}\text { Baseline } \\
\text { (Triliun Rp) }\end{array}$} & \multicolumn{4}{|c|}{ The change of welfare (\%) } \\
\hline & & $\operatorname{Sim} 1$ & $\operatorname{sim} 2$ & $\operatorname{Sim} 3$ & Sim 4 \\
\hline Farm-Worker Households & 572 & 0 & 0,52 & 0,52 & 0 \\
\hline Agricultural-Entrepreneur Households & 579 & 0 & 0,69 & 0,52 & 0 \\
\hline Low-Income Rural Households & 569 & 0 & 0,70 & 0,53 & 0 \\
\hline Non-Labor Force Rural Households & 535 & 0 & 0,75 & 0,56 & 0 \\
\hline High-Income Rural Households & 528 & 0 & 0,76 & 0,57 & 0 \\
\hline Low-Income Urban Households & 563 & 0 & 0,53 & 0,53 & 0 \\
\hline Non-Labor Force Urban Households & 534 & 0 & 0,75 & 0,56 & 0 \\
\hline High-Income Urban Households & 532 & 0 & 0,56 & 0,56 & 0 \\
\hline Firms & 940 & $-10,74$ & $-14,68$ & $-8,40$ & $-10,74$ \\
\hline Government & 572 & 0 & 0,52 & 0,52 & 0 \\
\hline
\end{tabular}

On the other hand, the increase in import tariffs by $50 \%$, would lead to the firms welfare decrease about 8.40 to $14.68 \%$. But when import tariffs is removed, firms welfare was also decrease $10.74 \%$. According to Anindita and Reed (2008), if the import tariff is removed, there will be a scheme to pay the loss of domestic producers because of the welfare in the economy will increase.

\section{CONCLUSIONS}

The rise of sugar import tariff $41.6 \%$ and $50 \%$ would increase the domestic output of sugar $1.89 \%$ and $3.77 \%$, sugarcane $7.69 \%$ andas $11.54 \%$, as well as other sectors, except the food and other agricultural crops; increase the volume exports, except for the food crops, and increasing import unless the sugar industry, agriculture and other services. The real income of households, producers and governments would fall, unless the tariff is set $41.6 \%$, the real income of households would increase. Household well-being of all agriculture and non-agriculture would rise from 0.52 to $0.76 \%$, but the welfare of producers fell from 8.40 to $14.68 \%$.

The abolition of import tariffs would reduce domestic output of food crops, other agricultural and services, but increased the volume of exports of food and beverage industry as well as other industries; and import volume of sugarcane and other agricultural. The real income all economic agent and producers will fall, but the well-being of the entire households have not changed. 
The government must to pay attention that if sugar import tariffs increase until $50 \%$, it will increase domestic output, especially sugar and sugarcane, as well as household income and household welfare, but it will reduce the income and welfare of producers. Thus, the relevant tariff depends on the purpose of the government whether to increase domestic output and import or export of certain sectors, and the welfare of producers or consumers.

\section{REFERENCES}

[1] Anindita, R. \& Reed, M.R. (2008). Bisnis dan Perdagangan Internasional. Penerbit Andi. Yogyakarta.

[2] Armington, P.A. (1969). A Theory of Demand for Products Distinguished by Place of Production. International Monetary Fund Staff Papers 16 (5): 159-78.

[3] Badan Pusat Statistik (2010). Sistem Neraca Sosial Ekonomi Indonesia 2008. Jakarta: BPS.

[4] Departemen Perindustrian (2009). Roadmap Industri Gula. Direktorat Jenderal Industri Agro dan Kimia Departemen Perindustrian. Jakarta.

[5] Hanemann, M. \& Morey, E. (1992). Separability, Partial Demand System and Consumer's Surplus Measures. Journal of Environmental Economics and Management 22, 241-258.

[6] Hosoe, N., Gasawa, K. \& Hashimoto, H. (2010). Textbook of Computable General Equilibrium Modelling: Programming and Simulations. New York: Palgrave Macmillan.

[7] Just, E. R., Hueth, D. L. \& Schmitz, A. (1982). Applied Welfare Economics and Public Policy. London: Prentice-Hall Inc.

[8] Lofgren, H., Harris, R. L. \& Robinson, S. (2002). A Standard Computable General Equilibrium (CGE) Model in GAMS. Microcomputers in Policy Research. International Food Policy Research Institute.

[9] Mapfumo, A., Mushunje, A. \& Chidoko, C. (2012). The Impact Of Government Agricultural Expenditure On Poverty In Zimbabwe. Received June 27, 2012. Russian Journal of Agricultural and Socio-Economic Sciences. ISSN 2226-1184.

[10] Markusen, J. \& Rutherford, T. (2004). MPSGE: A User's Guide. Department of Economics University of Colorado. Lecture Notes Prepare for the UNSW Workshop, February 24-27, 2004.

[11] Munongo, S. (2012). Welfare Impact Of Private Sector Interventions On Rural Livelihoods: The Case Of Masvingo And Chiredzi Smallholder Farmers. Russian Journal of Agricultural and Socio-Economic Sciences. ISSN 2226-1184. №10 October 2012.

[12] Robichaud, V. (2001). Calculating Equivalent and Compensating Variations in CGE Models. http://www.pep-net.org/fileadmin/medias/pdf/ev3.pdf. Diunduh Rabu, 6 Pebruari 2013.

[13] Sekretariat Negara Republik Indonesia (2009). Revitalisasi Industri Gula dan Komoditi Minyak Goreng. http://www.setneg.go.id. Diunduh 24 Juni 2012.

[14] Shoven, B.J. \& Whalley, J. (1992). Applying General Equilibrium. New York: Cambridge University Press.

[15] Varian H R (1992). Microeconomic Analysis, Third Edition, W.W. Norton \& Company, New York.

[16] Woods-Early, Y.S. (2006). Sugar Export Price And Import Tariff Reforms: A Computable General Equilibrium Analysis of Mauritius. Dissertation. University of Pittsburgh. 